\title{
Entitlement to Islands, Rocks and Low - Tide Elevations in the South China Sea: Geoeconomics versus Rule of Law
}

\author{
Professor Solomon E. Salako ${ }^{1}$ \\ ${ }^{1}$ School of Law and Archbishop Desmond Tutu Centre for War and Peace Studies, Liverpool Hope University, \\ Liverpool, United Kingdom \\ Correspondence: Professor Solomon E. Salako, School of Law and Archbishop Desmond Tutu Centre for War \\ and Peace Studies, Liverpool Hope University, Liverpool, United Kingdom. E-mail: salakos@hope.ac.uk
}

Received: May 3, 2018

doi:10.5539/ilr.v7n1p247
Accepted: May 27, $2018 \quad$ Online Published: August 17, 2018

URL: https://doi.org/10.5539/ilr.v7n1p247

\begin{abstract}
Entitlement to islands, rocks and low-tide elevations in the South China Sea is based either on historical claims under customary international law or on maritime claims under the United Nations Convention on the Law of the Sea 1982 (UNCLOS). China's 'entitlement' to islands, rocks and low-tide elevations in the South China Sea is based on historical claims spanning over two thousand years. However, there are other littoral claimants such as Taiwan, the Philippines, Vietman and Japan, and what is more, the United States is implicated in Japan's claim for historical and other reasons. The objects of this article are to evaluate the rule of law and geoeconomics in claims to islands, rocks and low-tide elevations in the South China Sea, especially the Philippines-China arbitration; to show that the historical and maritime claims intersect and collide; to evaluate the United States' involvement and the Thucydides trap; and to articulate the reasons why geoeconomics should guide not only the interpretation of UNCLOS but also state responses in terms of joint development and unilateral strategies.
\end{abstract}

Keywords: Islands, low-tide elevations, South China Sea, geoeconomics, rule of law

\section{Introduction}

The South China Sea covers an area of 648,000 square nautical miles and acts as a bridge between littoral states which include the People's Republic of China, Taiwan, Brunei Darusalam, Cambodia, Indonesia, Lao's People Democratic Republic, Malaysia, Myanmar, the Philippines, Thailand, Vietnam and, arguably, Singapore because one of Singapore's islands - Pedra Blanca - is situated in the South China Sea just beyond the Singapore Strait (Zou, 2015). Linked to the South China Sea in the south is the East China Sea which is part of the Pacific Ocean, covers an area of 482,000 square nautical miles, and serves as the main shipping route from the South China Sea to Japanese and other North Pacific ports (Shanghai in China, Nagasaki in Japan and Chi-Lung in Taiwan) (LaFond, 2017).

Located in the South China Sea are hundreds of small islands, rocks and low-tide elevations such as uninhabited islets, shoals, reefs, sands, bays and cays; some of these features are rich in natural resources such as oil and natural gas (Roy, 2016). The estimates of oil reserves near Spratly Islands range from 105 to 213 billion barrels while the gas reserves vary from 266 trillion cubic feet (TCF) to more than 2,000 TCF (Roy, 2016). Located also in the East China Sea are the Senkaku/Diaoyu Islands, a group of five uninhabited islands, some of which are rich in oil and natural gas.

China's 'entitlement' to 80 per cent of the islands and low-tide elevations in the South China Sea is based on discovery, occupation and historic rights spanning over two thousand years. The two largest archipelagos in the South China Sea, Paracel Islands and Spratly Islands, are claimed by China and the Philippines. China's 'entitlement' to other islands and low-tide elevations is challenged by other littoral states: Pratas (Taiwan), Paracels (Vietnam), Louisa Reef (Brunei and Malaysia) and Senkaku/Diaoyu Islands (Japan).

Claims to sovereignty over islands and low-tide elevations in the South China Sea and, one might add, over Senkaku/Diaoyu Islands in the East China Sea are based on acts of discovery, historic use, and occupation - a matter of customary international law. Maritime claims of territorial sea, continental shelf and exclusive economic zone are based on the provisions of the United Nations Convention on the Law of the Sea 1982 
(UNCLOS). UNCLOS does not allocate territorial sovereignty to land but creates its own title in terms of territorial sea and archipelagic waters. The two sets of rules do not subsume each other.

Since neither historical title nor the law of discovery and occupation can be understood in terms of treaty law and since no treaty law - including UNCLOS - can exhaust the rules of international law, the disputes in the South China Sea must be discussed not only in terms of the two legal systems outlined above but also in terms of geoeconomics (the use of economic tools to achieve geopolitical ends) because the solution of overlapping and contested claims in the South China Sea is not achievable under the rule of law and states, as we shall see in this excursus, prefer to ignore the jurisdiction or the decision of an international tribunal.

In this article, the themes to be discussed are as follows: the rule of law and geoeconomics in claims to islands, rocks and low-tide elevations in the South China Sea; the use of geoeconomic tools to achieve geopolitical ends; a critical analysis of the disputes in the South China Sea; UNCLOS, geoeconomics and thwarting the Thucydides trap; and the reasons why geoeconomics should guide not only the interpretation of UNCLOS but also the formulation of development and unilateral strategies on the islands, rocks and low-tide elevations in the South China Sea.

\section{The Rule of Law Revisited}

The Rule of Law is not law itself but an ethico-political doctrine which is regarded as an essential constituent of any law. It is a banner under which several armies march to battle: for Anglo-American politicians it has become "one of those self-congratulatory rhetorical devices that grace ... public utterances", and, for Geoffrey de Q. Walker "parliamentary omnipotence is an absurdity and ... legislative power must be balanced by rule of law not just as a set of safeguards but as a minimum standard for the substantive content of enacted law" (Shklar, 1987; Walker, 1988).

Historically, the origin of the Rule of Law has been traced to the extraordinary exchange between James I and Sir Edward Coke, Lord Chief Justice of Common Pleas in 1607. James I argued that he (the King) could withdraw cases from the judiciary and decide them for himself. But Coke retorted (quoting Bracton) that the King was subject to God and law. Coke was dismissed from the bench but later returned to the legislature where he played a leading role in the drafting of the 1628 Petition of Rights. The Bill of Rights Act was adopted in 1689 after a civil war, the beheading of one monarch and the overthrow and exile of a second. The Bill of Rights provided, inter alia, that it was illegal for the sovereign to suspend or dispense with laws, to establish his own courts, or to impose taxes without parliamentary approval. It also provided that the election of members of parliament shall be free, and that parliamentary proceedings shall be subject to scrutiny (Bingham, 2010). However, the fons et origo of the Rule of Law was not in the seventeenth century but Aristotle while reacting to Plato's assertion in The Republic that the best form of government was rule by a philosopher King (Grube, 1992). So Aristotle in Politics concluded that the rule of law was preferable to that of any individual (Saunders, 1992). Today, we have three versions of the Rule of Law: (i) the Aristotelian version adopted by John Adams on the eve of the American Revolution as the definition of a republic, that is, "a government of laws, not of men" (Note 1); (ii) the Diceyan formulation, and (iii) the Universalised Formula or International Rule of Law.

\subsection{The Diceyan Formulation of the Rule of Law}

A. V. Dicey, in his magnum opus - An Introduction to the Study of the Law of the Constitution - formulated the Rule of Law. There are three strands of the Diceyan formulation. The first strand enunciated the principle of absence of arbitrary power while the second is the principle of equality before the law. The third strand - that fundamental rights are the result of judicial decisions - is peculiar to the British Constitution and need not detain us here (Dicey, 1885).

\subsection{The Universalised Formula or the International Rule of Law}

The Universalised Formula or the International Rule of Law is the adaptation of the first two strands of the Diceyan formulation - absence of arbitrary power and equality before the law - in the international sphere. These two strands were adapted and expanded by the International Commission of Jurists, through its congresses, conferences and colloquium, in the Act of Athens 1955, the Declaration of Delhi 1959, the Law of Lagos 1961, the Resolution of Rio 1962, the Declaration of Bangkok 1965 and the Declaration of Colombo 1966 to meet the changing patterns of human relations as a result of the independence of several colonies (Note 2).

It must be stated, however, that International Rule of Law means different things to different people and is, therefore, problematic. The pertinent question is: Is there an International Rule of Law? 


\subsection{An International Rule of Law?}

According to Chesterman, the term 'International Rule of Law' could have three different meanings (Chesterman, 2008). It could mean the adaptation of the first two strands of the Diceyan formulation in the international sphere by the Conferences, Congresses and the Colloquium of the International Commission of Jurists discussed above. This is the first sense in which the International Rule of Law is understood.

It could privilege international law over national law. This second sense may be relevant to regional organisations like the European Union or the Association of Southeast Asian Nations (ASEAN) and their respective Member States. This is problematic because peoples and governments of the world are not ready for the surrender of their sovereignty to any type of world government.

The International Rule of Law could mean a global rule of law which might denote the emergence of a normative regime that touches individuals without mediation through existing national institutions. This third sense is problematic for the simple reason that under a national law the sovereign exists in a vertical hierarchy with other subjects of law while in international law sovereignty remains with states existing in a horizontal plane of sovereign equality.

What then is International Rule of Law? International Rule of Law, therefore, is the universalised formula, that is, the reliance on law as opposed to arbitrary government and the substitution of settlement by law for settlement by force (Bishop, 1960-61). The doctrine of the rule of law and its variant - the International Rule of Law - are alien to Chinese culture. As Fukuyama explains in The Origins of Political Order, the rule of law is "a pre-existing body of law representing the will of the community that is higher than the will of the current government and that limits the scope of the government's legislative act" (Fukuyama, 2011). But Fukuyama contends that there are three components of political development: state building, rule of law, and accountability. China, Fukuyama argues, built a central state in 221 B.C. at the time of the Qin Dynasty and merit-based bureaucracy that was able to register its population, levy taxes, control the military and regulate society some eighteen hundred years before a similar state emerged in Europe (Fukuyama, 2014). However, China has been a society ruled by law. The Communist Party, as in dynastic China, have never acknowledged the supremacy of law over the party. For them, law remains an instrument of rule, and not an intrinsic source of legitimacy. Lee Kuan Yew, the first Prime Minister of Singapore, opines that political freedoms are a Western priority which are alien to Asian values which are based on order, discipline and loyalty, rather than on liberty and freedom (Sen, 1999; Allison and Blackwill, 2013).

If then the rule of law is alien to Asian culture then geoeconomics should be considered not only as a paradigm but also as an interrogatory source.

\section{Geoeconomics}

The term "geoeconomics", which was used for the first time in 1942 by the American scientist, George T. Renner, is an amalgam of the logic of conflict and the grammar of commerce (Babić, 2009; Luttwak, 1990). It has been defined as "the systematic use of economic instruments to accomplish geopolitical objectives" (Blackwell and Harris, 2016). While there is a tendency to use the terms "geoeconomics" and "geopolitics" interchangeably, this tendency should be resisted at all cost (Note 3). The notion of "geopolitical social" draws attention to acts of violence that allowed the assemblage of national territory or the furtherance of national interests while the "geoeconomic social" is the recasting of the social forms of security through the market. Therefore, geopolitics and geoeconomics are two distinct forms of geostrategic discourse.

A neat illustration of the use of geoeconomics in the mid-twentieth century is the United States' orchestrated run on the British Pound to force a ceasefire and the withdrawal of British, French and Israeli forces from Egypt during the Suez Canal Crisis of 1956 (Salako, 2016). Since then, the United States has lost the art of using geoeconomics for geopolitical ends and has relied solely on one tool of geoeconomics - economic and financial sanctions - to further its geopolitical interests; and thus moving in the opposite direction and allowing China (the world's leading practitioner of geoeconomics) to extend its influence not only in Asia but worldwide. Whether sanctions work is a moot point but that should not detain us here. What matters in this excursus is to show how China has used five other tools of geoeconomics, namely, trade policy, investment policy, cyber attacks, aid and regulation of commodity flows in achieving its geopolitical goals in the disputes in the South China Sea and in driving a wedge between the United States and its allies (Japan, the Philippines and South Korea) (Note 4).

Trade as an economic tool can be used coercively as was the case when Beijing tried to dissuade Manila from claiming the Scarborough Shoal during the administration of President Benigno Aquino of the Philippines. Investment policy is a more potent geoeconomic tool which has been used by Norway with the largest sovereign 
fund in the world ( $\$ 810$ billion) to dissuade its firms from investing in Israeli firms with ties to settlements in the disputed West Bank territories. China's investment policy is predicated by the disavowal of Taiwan and the recognition of one - China policy, leaving Taiwan with just 22 allies (mostly small nations).

While little is known of the extent of cyber attacks, they have been used conjunctively with other geoeconomic strategy to persuade Japan to negotiate in the Senkaku/Diaoyu dispute, discussed later. Economic aid, like military aid, is a geoeconomic tool as old as diplomacy itself. One of the exponents of economic aid as a geoeconomic tool is the Gulf Corporation Council. Qatar, a member of the Council, provided $\$ 8$ billion and pledged \$12 billion to Egypt between President Mubarak's overthrow in February 2011 and Morsi's removal in 2013. Kuwait, United Arab Emirates and Saudi Arabia - all members of the Council - have given the sum of \$20 billion since Morsi's removal. China has not only been staying out of wars but has also been using its stupendous economic power in two ways. First, China has been using its economic power to create a new international order by setting up the Asian Infrastructure Investment Bank, capitalised at $\$ 100$ billion as an alternative to the World Bank; and, second, China's $\$ 900$ billion so-called "One Belt, One Road" initiative which includes pipelines and a port in Pakistan, bridges in Bangladesh and railways to Russia offers alternative values and institutions different from those promoted by cosmopolitans/liberals and neoconservatives such as the rule of law, world government, IMF and World Bank (Note 5).

Finally, China's claim to territorial sovereignty and the development of oil and gas around the disputed islands and low-tide elevations have led to the regulation of commodity flows to influence actions surrounding the territorial disputes in the South China Sea which are now discussed in depth.

\section{South China Sea Disputes}

There are five disputed groups of islands, rocks and low-tide elevations: (i) the Paracel Islands, (2) the Louisa Reef and Riflemen Bank, (3) Pratas Islands, (4) Spratly Islands, and (5) Senkaku/Diaoyu Islands.

\subsection{Paracel Islands}

From the beginning of the nineteenth century to the early twentieth century China made claims to Paracel Islands without effective control based on the fact that their ships had sailed across the South China Sea for two thousand years and used the sea as a regular navigation route during the Han Dynasty (206-220AD) and that these voyages increased in frequency during the Tang Dynasty (618-906AD).

Vietnam claimed that since the early seventeenth century it exercised state power over these uninhabited islands. This claim to sovereignty is based on the right of cession from the French claim to the islands made in 1933. Although the French Government claimed these islands, it did not occupy them after Japan surrendered in 1945. In the 1951 San Francisco Peace Treaty, Japan renounced its rights and claims to the Paracels and Spratlys but left the transfer of title unresolved. South Vietnam and China subsequently issued official declarations incorporating the Paracels as sovereign territory in 1956 and 1958 respectively (Chong and Hall, 2017).

In 1970, the prospect of offshore oil intensified the dispute. By mid-1973 Saigon granted energy exploration rights to Western companies. On 19 January 1974 the Chinese and South Vietnamese navies clashed near the disputed Paracel Islands. The convergence of economics, geopolitics and territorial claims drew the two countries into an escalatory crisis. After the cessation of hostilities, the whole Paracels, which is of geostrategic value to China, was under Chinese control (Yoshihara, 2016).

\subsection{Louisa Reef, Riflemen Bank and Pratas Islands}

Brunei claims Louisa Reef (also claimed by Malaysia) and Riflemen Bank. Brunei's claim to Louisa Reef is weak because only two rocks are above water at high tide and these rocks do not generate continental shelf or exclusive economic zone (Note 6).

Taiwan's claim to Pratas Islands is based not only on long-standing historical ties but also on physical presence when Japan withdrew after World War II. Although Taiwan refers to itself not only as the Republic of China but also as the legitimate government of China, the one-China policy and China's investment policy predicated by the disavowal of Taiwan are effective counterweight to Taiwan's claim.

\subsection{The Spratly Islands}

The Spratly Islands, rich in oil and natural gas and notorious as a hazard to navigation and the site of longstanding territorial disputes among littoral states, consist of hundreds of high-tide elevations, low-tide elevations and submerged features.

To facilitate exposition, high-tide features are "rocks" and fully-entitled "islands"; low-tide elevations are shoals, reefs, cays and banks; and submerged features are features that are fully submerged. 
The term "island" is defined in Article 121(1) of UNCLOS as "a naturally formed area of land, surrounded by water, which is above water at high tide"; and the geological or geomorphological characteristic for a high-tide elevation are not relevant for its classification pursuant to Article 121(3) which provides:

"Rocks which cannot sustain human habitation or economic life of their own shall have no economic zone or continental shelf."

In other words, the status of a feature is to be determined by its natural capacity without external capacity and without modifications to increase its capacity to sustain human habitation or an economic life. It is arguable that if harbour reclamation qualifies as addition to state territory, this opens the possibility of artificially extended islands (rocks) (Kwiatkowska and Soons, 1990).

In In the Matter of the South China Sea Arbitration (Republic of the Philippines $v$ The People's Republic of China) (the Philippines - China arbitration) (Note 7), the Philippines asked the Permanent Court of Arbitration (the Tribunal) to resolve a series of disputes between the parties. Cutting away the frills, the declarations sought are as follows:

(1) A declaration that China's rights in the South China Sea must be based on UNCLOS and not on any claim to historical rights; and

(2) A declaration that China's right to 'nine- dash-line' marked on Chinese map are not permitted by UNCLOS and are without legal effect.

The Philippines asked the Tribunal to resolve the following disputes:

(1) A dispute between the Parties concerning maritime zones that would be generated under UNCLOS by Scarborough Shoal and certain islands and low-tide elevations in the Spratlys; and

(2) A series of disputes concerning China's violation of UNCLOS such as interference with fishing rights, protection of marine environment, the construction of artificial islands and land reclamation at seven reefs in the Spratly Islands.

China rejected the Philippines' recourse to arbitration and refused to participate in the Tribunal's proceedings by invoking Article 9 of Annex VII to UNCLOS (Note 8). The position of China, gleaned from contemporary official statements, is as follows:

1) That the Cairo Declaration stated that it was the purpose of the three Great Allies that Japan shall be stripped of all the islands seized, occupied or stolen by Japan and that they shall be returned to the Republic of China.

2) That the nine-dash-line indicated the geographical scope of its authority over the South China Sea.

3) That on May 29, 1956 - after the founding of the People's Republic of China - China issued a statement that Spratly Islands are inherently Chinese territory.

4) That China, on depositing the instrument of ratification of the UNCLOS on 7 June 1996, stated that the People's Republic of China reaffirms its sovereignty over all its archipelagos and islands listed in Article 2 of the Law of the People's Republic of China on the territorial sea and contiguous zone, which was promulgated on 25 February 1992.

5) That on 26 June 1998, China promulgated its law on the Exclusive Economic Zone (EEZ) and the Continental Shelf. Article 14 provides that provisions of this law does not prejudice "historic rights" enjoyed by China.

6) China claims historical title based on the doctrines of recognition, acquiescence and estoppel.

7) Although UNCLOS is a comprehensive statement of law, it was never intended at the time of its adoption to exhaust international law (Gao and Jia, 2013).

The Philippines' claim to most of Spratly Islands, at the Tribunal, is more recent and based on the theory that the islands were res nullius or abandoned after World War II. The basic principle of international law is that a state occupies a definite part of the earth to the exclusion of other states, subject to the limitation of international law. A state's authority over a definite part of the earth - a territory - is what is popularly known as "sovereignty". There are five methods of acquiring territory under customary international law before the promulgation of UNCLOS 1982, viz, (i) occupation, (ii) cession, (iii) conquest, (iv) prescription, and (v) accretion.

Occupation was a means of acquiring territory but the old way of treating the land inhabited by tribal communities as terra nullius has now been discredited. The preponderance of opinions of jurists was that 
territories inhabited by tribes or peoples having social or political organisations were not to be regarded as terra nullius (Chapman, 2012). The acquisition of sovereignty was not considered as effected by the general "occupation" of terra nullius but through agreement concluded by the local rulers. Such an acquisition whether considered as "cession", discussed later, was a derivative root of title, not an original title (Note 9). Again, terra nullius has no territorial sea as the doctrine of appurtenance - if "appurtenance" means belongs to something else - does not apply and the adjacent water should simply be regarded as high seas (Crawford, 2012).

In the Legal Status of Eastern Greenland, the Permanent Court of International Justice pointed out that a title by occupation involved two elements: (i) the intention or will to act as a sovereign, and (ii) some actual exercise or display of authority. The Court added that occupation, in order to create a title to territory, must be "effective" (Note 10). Since all habitable parts of the earth are under the dominion of one state or others, future titles are no longer possible, but the law matters because past occupations give rise to future conflicts.

From the requirement instantiated above, that occupation must be "effective", it follows that the discovery of an unappropriated territory is not sufficient to create a title. In the Island of Palmas award (Netherlands $v$ USA), the United States, having acquired the Philippines for \$20 million under the Treaty of Paris 1898 with Spain, claimed as Spain's successor an island which was halfway between the Philippines and the Dutch East Indies on the ground of its discovery by the Spanish in the sixteenth century. Max Huber, the Swiss arbitrator, stated that even if international law of the century recognised discovery or giving title to a territory, discovery alone was not sufficient (Note 11). He concluded that the claimed title could not prevail over the continuous display of authority, which the evidence satisfied him, Holland had exercised. In Clipperton Island case, it was held that immemorial usage having the force of law, besides animus occupandi, the actual and not the nominal taking of possession, is a necessary condition of occupation (Note 12).

Cession is a method of transferring title of a territory from one state to another. The oft-cited example is the sale of Alaska by Russia to the United States in 1867 for a sum of $\$ 7.2$ million. Conquest or subjugation, the complete subjugation of a state and declaration of the conquering state to annex it is proscribed (Note 13).

Prescription is the removal of defects in a putative title arising from the usurpation of another's sovereignty by the acquiescence of the former sovereign. Some eminent jurists accept it as an institution of international law but others reject it.

Accretion is the addition of a new territory to an existing territory of a state by operation of nature such as the recession of a sea or the drying of a river.

The first problem is: What exactly is the juridical basis of the Tribunal's decision to grant most of the declarations and hold in favour of the Philippines' submission that any rights that China might have had in the maritime areas were extinguished by China's accession to UNCLOS and that China never had historic rights? The Tribunal's decision that China had no historical rights and the arguments in favour of this position are unconvincing and are trite jurisprudence as we shall see in this excursus.

The claims over the islands in the South China Sea are sovereignty claims. UNCLOS provides for the regime of islands (Articles 121-123 of UNCLOS) but does not provide for mechanisms for solving competing historical and maritime claims to the islands. UNCLOS creates titles in its own way over territorial sea or archipelagic waters but deliberately avoids the use of the word "sovereignty" redolent of "territorial sovereignty"; instead, the term "sovereign rights" is used (Note 14). The preamble to UNCLOS affirms that "matters not regulated by this Convention [i.e., UNCLOS] continue to be governed by the rules and general principles of international law" (Note 15). UNCLOS does not exhaust the rules of international law: customary international law and treaty law intersect and collide.

The Philippines claim, as stated in their submission to the Tribunal above, is not based on the Treaty of Paris 1898. If, in the eighteenth century Spain discovered and included the features in the boundary of the Philippines ceded to the United States, then the feature (Scarborough Shoal) was not terra nullius in 1898 based on the classical doctrine of occupation discussed above. The territory was also not part of the Philippines because the territory ceded by the treaty to the United States has been reaffirmed in the Philippines Constitution of 1935 and did not include the feature. The Philippines claim that any rights China might have had in the maritime areas of the South China Sea beyond those provided by the Convention were extinguished by China's accession to the treaty and the upholding of this claim by the Tribunal must be treated with some circumspection for two reasons. First, the treaty (UNCLOS) does not subsume the customary law. Second, the authorities, cited by the Tribunal, pull at different directions.

In the Gulf of Maine between the United States and Canada, historic rights in or to exclusive economic zone of a 
neighbouring state were in issue. The area to be delimited included Georges Bank with its abundant fisheries resources and the United States argued that the delimitation line should take cognisance of long standing use of the bank by fishermen. The International Court of Justice not only rejected this argument, but also considered the effect on US fishing activities of the adoption by the United States and Canada of exclusive fishing zones. The Court noted the factual predominance of the United States in the area it had been able to secure which became, under UNCLOS, legally part of its own exclusive zone and that, conversely, to the extent that they had become part of the exclusive zone of the neighbouring state, reliance could not be placed on the predominance (Note 16). Two other cases are worth noting. They are Fisheries Jurisdiction (United Kingdom v Iceland) (Note 17); and Fisheries Jurisdiction (Federal Republic of Germany v Iceland) (Note 18). In these cases, which concerned the declaration of a 50-nautical-mile exclusive fishing zone, the International Court of Justice held that the regulations concerning a unilateral extension of fishing rights asserted by Iceland were not opposable to either the United Kingdom or the Federal Republic of Germany and that Iceland could not extinguish the rights of other states who have habitually fished in the area. If the Tribunal's view in the Philippines - China arbitration is that these decisions were to be understood in the context of the law of the sea, as it then was, two subsequent decisions cast serious doubts on their assumption.

In Eritrea $v$ Yemen arbitration, the arbitral tribunal emphasised the importance of preserving traditional fishing practices in the Red Sea which had been carried out for centuries without specific reference to maritime boundaries and held that "the traditional fishing regime is not limited to the territorial waters of specific islands" but extended also through the exclusive economic zones of Eritrea and Yemen (Note 19). More recently, in Chagos Maritime Protected Area (Mauritius v United Kingdom) (2015), the Tribunal held that Mauritius had rights in the exclusive economic zone declared by the United Kingdom surrounding the British Indian Ocean Territory. In that case, the United Kingdom did not argue that Mauritius's rights were extinguished by the United Kingdom's declaration of an Environmental Protection and Preservation Zone/Fisheries Conservation and Management Zone but also maintained its undertaking that the zone it had created was not an exclusive zone for the purposes beyond fishing and environmental protection (Note 20).

The other contentious issues are China's construction activities on reefs in the Spratly Islands. The Philippines submits that China's activities at Mischief Reef (between 1999 and 2013) and other seven coral reefs (from 2014 to 2015) violate Articles 60 and 80 of UNCLOS relating to artificial islands, installations and structures and constitute unlawful acts of attempted expropriation under the Convention. The Tribunal held that China breached Articles 60 and 80. The problem, as this author sees it, is the juridical status of the islands. If they can be assimilated neither to islands nor to ships, the question - which law is to regulate the activities of the inhabitants of artificial islands? - remains unanswered.

\subsection{The Senkaku/Diaoyu Islands}

The only way to see the tension over these islands which has existed between Japan and China since the 1970s is to see it from a geoeconomic perspective. The five islands northeast of Taiwan called Senkaku Islands by Japan and Diaoyu Islands by China (hereafter Senkaku/Diaoyu Islands) are not only linked to China's "core interests" but there are also Ming Dynasty references to the islands and nineteenth century Japanese government reference to the proprietary attitude of Qing Dynasty towards the islands. Japan's claim is based on seizure during the Sino-Japanese War of 1894-95 (Swaine, 2013).

The United States' implication in the disputes complicates matters. After World War II, Senkaku/Diaoyu Islands were included in the territory taken from Japan as part of the post-World War II management of territories seized by Japan during the conflict but were returned to Japan in a backdoor deal incompatible with the norms of international law. As instantiated above, conquest or subjugation as a means of acquiring territory has been proscribed (Note 21). The real reason for this arbitrary return of the islands by the United States to Japan in the early 1970s was to use Senkaku/Diaoyu Islands in order to contain China and undermine its maritime interests; and what is more, the US-Japan Security Treaty brings any dispute with Japan, an ally of the United States, within the purview of the treaty. However, the response of China to the alleged provocative Tokyo's purchase of parts of these islands to prevent a conservative Japanese governor from buying the islands provides an insight into the use of geoeconomic strategy to drive a wedge between two allies with a joint security treaty. Beijing retaliated by ordering a massive boycott of Japanese products in China, by halting the shipment of rare earth oxides which are crucial components in Japanese industries, and by forcing foreign companies such as Hitachi Metals and Toyota reliant on rare earths to move to China, thus actualising Beijing's plan to grow domestic rare earths industry. China's use of geoeconomic statecraft got the message through to Japan, in spite of its ally (the United States). This brings us to China's accession to UNCLOS, its rejection of the rule of law and the jurisdiction of the Permanent Court of Arbitration, and the proffered reaction of the United States to China's 
geoeconomic statecraft, the so-called Thucydides's trap.

\section{UNCLOS, Geoeconomics and the Thucydides Trap}

Historically, there was little interest in the South China Sea before the twentieth century. France, in the 1930s, claimed both the Paracel and Spratly Islands and Japan took charge until its defeat in World War II. The claimant states in the South China Sea have different bases for their claims to islands, rocks and low-tide elevations in this "boiling cauldron" (Kaplan, 2015).

Claims to sovereignty over these features are based on discovery, historic use and occupation while claims to maritime zones are based on UNCLOS which provided an incentive for the acquisition of vast maritime zones by each of the littoral states through the regimes of territorial sea and continental shelf (Articles $1-32$ and 76 - 85) and exclusive economic zone (Articles 55 - 75); and what is more, economic competition, super power logic and nationalism provided an incendiary to conflict in the South China Sea.

\subsection{UNCLOS}

Prior to 1945, the concept of continental shelf was not part of international law, though a number of states made claims to their offshore submerged areas to secure resources contained therein; for example, the well known Truman Proclamation of 1945. Scholarly views on the concept of continental shelf at the United Nations Conference on the Law of the Sea 1958 were not coherent. There were scholars who relied on the submarine shelves being appropriated unilaterally or upon effective occupation as terra nullius in the existing international order while others contended that the continental shelf belonged ipso jure to the coastal state. The problem with these points of view is the juridical basis of unilateral declaratory claims to the territory (Note 22).

The other problem is that the disputes in the South China Sea are about sovereign rights over the islands and UNCLOS has no mechanism for dealing with sovereign rights but created its own rights over maritime zones. It is true that China, like other littoral claimants, acceded to UNCLOS but the fact remains that China, on depositing the instrument of ratification on 7 June 1996, stated that "the People's Republic of China reaffirms its sovereignty over all its archipelagos and islands listed in Article 2 of the Law of the People's Republic of China on the territorial sea and the contiguous zone, which was promulgated on 25 February 1992" (Note 23). The interests of the United States in the South China Sea are geopolitical and geostrategic. China's long-term intention is to become the greatest power in the world, not an honorary member of the West (Note 24). To this end, China's strategy for South East Asia is to 'suck in' countries such as Japan and South Korea into its economic orbit and become the largest economic power in the world. China's strategic interest requires dominance of the South China Sea. How is this to be achieved?

\subsection{China's Geoeconomic Statecraft}

If China's strategy is to dominate the South China Sea and to prevent third-party states like the United States from intervening in its disputes with other littoral states, then China seems to be succeeding as it weakens the current U.S. alliance system. As stated above, China's leverage with Japan on the Senkaku/Diaoyu disputes was geoeconomic: military confrontation was avoided, and geoeconomic statecraft was used to weaken Japan's resolve and to avoid a third-party involvement under the guise of the 1951 US-Japan Security Treaty where, by virtue of Article 9, Japan outsourced the important element of its security - the capacity to self-defence - to the United States (Note 25).

The Philippines also enjoys mutual defence treaty with the United States and even has an American-style constitution which is difficult to operate in non-Western countries as neatly illustrated by Nigeria - the sixth largest exporter of crude oil in the world and yet not a world economic power because of corruption, gross mismanagement and lack of "embedded autonomy", a term discussed later in this excursus. The Philippines lag behind other littoral states in the region - China, Singapore, Malaysia, Indonesia and South Korea - in terms of economic development. The ruling illusion is that the rule of law and democracy have a major role in economic development. It is true that the Philippines has a US-style constitution with a complete separation of powers between the executive, the legislative and the judiciary but the fact remains that the exuberance of democracy in a developing country leads to undisciplined and disorderly conditions which are inimical to development (Note 26). The economic success of the Asian tigers - China, Malaysia and Singapore - casts serious doubts on the assumption that the rule of law and democracy go hand in hand with development (Chan, 2002). What is required for development, as the embedded autonomy theory ordains, is either a strong democratic or a strong autocratic state with capacity to pursue long-term goals and to respond to social needs and free from pressure to satisfy rent-seeking constituencies (Fukuyama, 2014). The Philippines, lacking these attributes, came in for similar geoeconomic treatment as Japan. 
In 2012, after the skirmish over the disputed Scarborough Shoal when the Philippines' naval ship attempted to arrest Chinese fishermen, China refused to allow 150 containers of bananas to enter its market on the pretext that they were crawling with insects, costing the Philippines agricultural sector a loss of some US $\$ 760,000$ and a hard knock to Philippines' fruit exports, 30 per cent of which went to China. The response of the United States, an ally of the Philippines, was lukewarm and showed lack of geoeconomic acumen: the United States accepted more fruits from the Philippines but that was not enough to help Manila with Beijing's heavy-handed use of geoeconomics. President Benigno Aquino's regime relented and Beijing abandoned the economic coercion.

Again, in 2013, Beijing blocked President Benigno Aquino from attending the China-ASEAN trade expo to compel the Philippines to withdraw the Philippines - China arbitration before the Permanent Court of Arbitration. Aquino decided not to attend, missed potential trade opportunities with other states in the region, and pressed on with the arbitration. As we noted above, the Philippines won on most of the declarations sought at the Arbitral Tribunal but it was a Pyrrhic victory. China's leverage through bilateral trade in the region is so strong that its geoeconomic reach was difficult to resist. China's bilateral trade with ASEAN in 2013 reached $\$ 350$ billion (\$36.4 billion with the Philippines) (Note 27). President Rodrigo Duterte seems to have ignored the findings favourable to Manila in the Philippines - China arbitration and it is now business as usual with Beijing.

This brings us to Vietnam. Unlike Japan and the Philippines, Vietnam has no treaty with the United States. Vietnam wants the United States as a counterweight to China but the likelihood of the US signing a Defence Treaty with Vietnam seems remote, even absurd, in view of the Vietnam War (1 November 1955 to 30 April 1975). In the encounter with China over the Paracel Islands, which are now under China's control, Vietnam sought assistance from the US Seventh Fleet but to no avail (Yoshihara, 2016). As a matter of fact, Hanoi is more vulnerable to Beijing than Manila because it depends on rubber and major Chinese imports which are used in goods that Vietnam exports. That leaves us with Cambodia, a country that has been under intense pressure from China since 2009, in spite of UN objections, to agree to the extradition to China of twenty Uighurs seeking asylum in Cambodia. When Phnom Penh acceded to Beijing's request, it was rewarded with US $\$ 1.2$ billion in loans and grants and a shipment to Cambodia of 200 military and 257 non-military trucks.

China has used its geoeconomic power to prevent Taiwan from seeking independence and as a dominant economic power in the South China Sea it attracts more imports and exports from its neighbours than the United States in the region and, in time, Japan, Taiwan, South Korea and it seems other ASEAN countries will be integrated into China's economy. As Lee Kuan Yew, a shrewd political observer, stated: "China's growing economic sway will be difficult to fight" (Allison and Blackwill, 2013). But the rise of nationalism in South East Asia, the territorial disputes and military security in the region bring to focus the Thucydides trap.

\subsection{The Thucydides Trap}

The term 'Thucydides trap' is named after Thucydides, the ancient Greek historian, who two and half thousand years ago, chronicled the friction between a rising Athens and the established but suspicious Sparta which resulted in the Peloponnesian War (431-404BC).

Of the sixteen cases of friction between rising and established states in the past five hundred years, twelve ended in wars and four did not (Allison, 2017). The pertinent question is: Will China (a rising power) and the United States (an established and suspicious power) go to war? Realists believe that it is inevitable because China's economy and military power will dominate South East Asia and, therefore, the South China Sea and that any attempt by the United States to resist the inevitability of China's hegemony is likely to result in a catastrophic war between China and the United States or a humiliating climbdown for the latter. The realist position is worth assessing historically, geoeconomically and geostrategically.

Historically, drawing parallels from Sparta's reaction to Athens and Britain's response to Germany (examples to the Thucydides case file instantiated above) to illustrate how the dynamics of the rise by a state can lead to other states forming alliances to counterbalance, is inadequate as we intend to show. Historical parallels often overlook the complexities of individual circumstances and invite simplistic analaysis which adds very little to our genuine understanding of the matter discussed. From a historical perspective, the alliances of today in the South China Sea (US with Japan, Taiwan, Korea and the Philippines) are not the same as the alliances in decades before World War I which in order to prevent bloodshed, constructed a scenario which allowed an assassination to trigger a war (Allison, 2017). As noted above, the treaties between the US and the littoral states mentioned are amenable to China's geoeconomic statecraft.

Again, it is not unreasonable to assert that China is likely to push the United States out of Asia in the same way that the United States pushed the European powers out of the Western Hemisphere. By 1770, the Caribbean - an area stretching from Florida to Venezuela and the Gulf of Mexico including the Greater Caribbean that united the 
North and South America - was (and still is) roughly the size of the South China Sea and was the colonial possession of some European states. Sugar plantation, trade in goods and slavery were the mainstay of the Caribbean economy. With the abolition of slavery, the European enthusiasm for the Caribbean dissipated. This was the time the United States emerged as an imperial force in the Greater Caribbean. In 1823, President John Monroe enunciated what is known as the Monroe Doctrine: that the Western Hemisphere was no longer open for European colonisation or foreign interference. Britain was the only naval power that could challenge the United States. By 1903, Britain had acquiesced in the United States supremacy in the Western Hemisphere because the US economic influence based on geographical proximity surpassed that of Britain just as China's influence has come to surpass the influence of the United States in Asia (Kaplan, 2015).

The IMF Report of 2014 announced that China was the world's largest economy in terms of purchasing power index (Note 28). China has also set up parallel structures such as The Asian Infrastructure Investment Bank designed to systematically realign the international order away from the United States. As at the time of writing, China has lured some 84 countries (64 member states and 20 prospective member states) to join its new bank including the United Kingdom, Germany and twelve other members of the advanced economies of the G20 and, despite US opposition, every ally of the United States, excluding Japan, is a member. In the bulk of known history, the United States has not faced an adversary greater than China and the strategic tests facing the United States are geoeconomic.

\section{Conclusions}

The entitlement to islands, rocks and low-tide elevations in the South China Sea is based on claims to "territorial sovereignty" under customary international law which intersect and collide with maritime claims under UNCLOS. UNCLOS has no mechanism for determining sovereignty over contested islands and features but in creating rights of its own the word "sovereignty" redolent of territorial sovereignty was avoided; instead, the term "sovereign rights" was used to denote rights acquired over maritime zones (Crawford, 2012; Shaw, 2012).

It is reasonable for China to base its claim to islands, rocks and low-tide elevations on historical rights spanning over two thousand years. It is also not unreasonable for China to be the dominant power in the South China Sea just as the United States is in the Western Hemisphere. In geostrategic terms, the United States' interest in the South China Sea is the containment of China through various treaty alliances, especially those with the Philippines, Japan and South Korea.

Hegemony is moving from West to East and China's strategy for becoming the greatest power in the world is not to challenge a stronger and technologically superior power but, in the words of Deng Xiaoping, to:

"Coolly observe, calmly deal with things, hold your position, hide your capacities, bide your time and accomplish things where possible." (Note 29).

China's policy of "hide" and "bide", its dominance in Asia, its economic power - the largest economy in the world based on purchasing power index - and its systematic realignment of the international order (instantiated above) cast serious doubts on the Thucydides trap, the realist assumption that war between China and the United States is inevitable. If China is the largest economy in the world and the United States cannot stop China's stupendous economic rise, then there is an overwhelming reason for the United States to share its preeminent position with China.

China, the most powerful of the littoral states in the South China Sea, rejects not only the rule of law as a Western doctrine which is alien to Chinese culture but also refuses to acknowledge the jurisdiction of the Permanent Court of Arbitration, preferring, as mooted by Deng in 1984, negotiations on the joint development of the disputed islands and features before discussing the question of sovereignty (Jacques, 2012).

In the foregoing excursus, China, Vietnam and the Philippines emerge as the three major littoral claimants to the two largest islands in the South China Sea (the Paracels and Spratlys). China rejected the jurisdiction of the Permanent Court of Arbitration while the Philippines, having won a Pyrrhic victory, decided to set it aside for geoeconomic reasons. Instead of the rule of law, geoeconomics drives the national policies of the littoral states such as China, Malaysia and Vietnam and even the allies of the United States - the Philippines, South Korea and Japan.

Since there is no solution in sight mutually acceptable to the littoral states under the intersecting and colliding customary law dealing with historic rights to "sovereignty" and the UNCLOS dealing with "sovereign rights" over maritime zones, it is submitted that geoeconomics (as defined and applied above) should not only guide the interpretation of UNCLOS, but also state responses in terms of joint development and unilateral strategies on the disputed islands, rocks and low-tide elevations in the South China Sea (Note 30). 


\section{Acknowledgements}

This paper was presented on $2^{\text {nd }}$ May 2018 as a Professorial Lecture at Liverpool Hope University, United Kingdom. Thanks to the anonymous referees for their informed and constructive comments.

\section{References}

Allison, G. (2017). Destined for War: Can America and China Escape Thucydides Trap? (pp. 211-212). London: Scribe.

Allison, G., \& Blackwill, R. D. (2013). Lee Kuan Yew: The Grand Master's Insights on China, the United States and the World (pp. 116-119). Cambridge, Mass.: M. I. T. Press.

Babić, B. S. (2009). Geo-economics - Reality \& Science. Megatrend Review, 6(1), 27-54.

Bingham, T. (2010). The Rule of Law. London: Allen Lane.

Bishop, W. W. (1960-1961). The International Rule of Law. Michigan Law Review, 59, 554.

Blackwill, R. D., \& Harris, J. M. (2016). War by Other Means: Geoeconomics and Statecraft. Cambridge, Mass.: The Belknap Press of Harvard University Press. https://doi.org/10.4159/9780674545960

Chan, S. (2002). Liberalism, Democracy and Development. Cambridge: Cambridge University Press. https://doi.org/10.1017/CBO9780511491818

Chapman, A. (2012). Brierly's Law of Nations: An Introduction to the Role of International Law in International Relations (7th ed.). Oxford: Oxford University Press.

Chesterman, S. (2008). An International Rule of Law? The American Journal of Comparative Law, 56, 331-361. https://doi.org/10.5131/ajcl.2007.0009

Chong, J. I., \& Hall, T. H. (2017). One Thing Leads to Another: Making Sense of East Asia's Repeated Tensions. Asian Security, 13(1), 20-40. https://doi.10.1080/14799855.2017.1284795

Crawford, J. (2012). Brownlie's Principles of Public International Law (8th ed., pp. 251). Oxford: Oxford University Press. https://doi.org/10.1093/he/9780199699698.001.0001

Dicey, A. V. (1945). An Introduction to the Study of the Law of the Constitution (9th ed., pp. 118-195). London: Macmillan.

Fukuyama, F. (2011). The Origins of Political Order: From Prehuman Times to the French Revolution (pp. 253). London: Profile Books.

Fukuyama, F. (2014). Political Order and Political Decay: From the Industrial Revolution to the Globalisation of Democracy (pp. 336). London: Profile Books.

Gao, Z., \& Jia, B. (2013). The Nine-Dash- Line in the South China Sea: History, Status and Implications. The American Journal of International Law, 107, 98-124. https://doi.org/10.5305/amerjintelaw.107.1.0098

Grube, G. M. A. (1992). Plato: Republic, revised by C. D. C. Reive. Indianapolis, Indiana: Hacket Publishing Co.

International Commission of Jurists. (1966). The Rule of Law and Human Rights: Principles and Definitions. Geneva.

Jacques, M. (2012). When China Rules the World: The End of the Western World and the Birth of a New Global $\operatorname{Order}$ (pp. 377). London: Penguin.

Kaplan, R. D. (2015). Asia's Cauldron: The South China Sea and the end of a stable Pacific (pp. 17 - 50). New York: Random House.

Kwiatkowska, B., \& Soons, A. H. A. (1990). Entitlement to Maritime Areas of Rock Which Cannot Sustain Human Habitation or Economic Life of Their Own. Netherlands Yearbook of International Law, 21, 169-171. https://doi.org/10.1017/S0167676800002087

LaFond, E. C. (2017). East China Sea. Encyclopaedia Britannica. Retrieved from https://www.britannica.com/place/east-china-sea

Luttwak, E. N. (1990). From Geopolitics to Geo-Economics: Logic of Conflict, Grammar of Commerce. The National Interest, 20, 17-23.

Rachman, G. (2016). Easternisation: War and Peace in the Asian Century (p. 49). London: The Bodley Head.

Roy, N. (2016). The South China Sea Disputes: Past, Present, and Future. Lanham: Lexington Books. 
Salako, S. E. (2016). Forcible Protection of Nationals Abroad and Humanitarian Intervention: Might or Right? International Law Research, 5(1), 152-167. https://doi.10.5539/ilr.v5n1p152

Saunders, T. V. (1992). Aristotle: The Politics, translated by T. A. Sinclair. London: Penguin.

Sen, A. (1999). Development As Freedom (pp. 231). Oxford: Oxford University Press.

Shaw, M. N. (2014). International Law (7th ed., pp. 426). Cambridge: Cambridge University Press.

Shklar, J. (1987). Political Theory and the Rule of Law. In A. Hutchinson, \& P. Monahan (Eds.), The Rule of Law: Ideal or Ideology (pp. 1). Toronto: Carswell.

Singh, S., \& Yamamoto, L. (2017). China's artificial islands in the South China Sea: geopolitics versus Rule of Law. Revisita de Direito Econômico e Socioambiental, $8(1), \quad$ 1-23. https://doi.10.7213/rev.dir.econ.soc.v8il.7451

Swaine, M. D. (2013). Chinese Views Regarding the Senkaku/Diaoyu Islands Dispute. China Leadership Monitor, 41, 1-27. Retrieved from http://media.hoover.org/documents/CLM41MS.pdf

Walker, G. de Q. (1988). The Rule of Law: Foundations of Constitutional Democracy (pp. 359). Melbourne: Melbourne University Press.

Yoshihara, T. (2016). The 1974 Paracels Sea Battle: A Campaign Appraisal. Naval War College Review, 69(2), 41-65.

Zou, K. (2015). The South China Sea. In D. R. Rothwell, A. G. O. Elferink, K. N. Scott, \& T. Stephens (Eds.), The Oxford Handbook of the Law of the Sea (Ch. 28). Oxford: Oxford University Press.

\section{Notes}

Note 1. John Adams, Novanglus No. 7 (January 1775) available at https://danglas-sarchives.org/adam_a50.htm

Note 2. See International Commission of Jurists (1966).

Note 3. See Singh and Yamamoto (2017).

Note 4. See Blackwill and Harris (2016: 49).

Note 5. Rachman (2016: 58).

Note 6. See Article 121(3) of UNCLOS.

Note 7. Permanent Court of Arbitration: PCA Case No. 2013 - 19 (2016), available at https://pca-cpa.org/wp-content/uploads/sites/175/.../PH-CN-20160712-Award.pdf

Note 8. Article 9 of Annex VII of UNCLOS provides:

"If one of the parties to the dispute does not appear before the arbitral tribunal or fails to defend its case, the other party may request the tribunal to continue the proceedings and make its award."

Note 9. Advisory Opinion on Western Sahara (1975) ICJ Reports, p. 12, at para. 80.

Note 10. PCIJ, Series A/B (33) No. 53.

Note 11. (1921) RIAA, Vol. II, 829-71.

Note 12. Arbitral Award on the Subject of Difference Relative to the Sovereignty over Clipperton Island (Clipperton case) (1932) 26 The American Journal of International Law 390 - 394.

Note 13. See the UN General Assembly's Declaration of the Principles of International Law Concerning Friendly Relations and Cooperation Among States in Accordance with the Charter of the United Nations, Res. 2625, 24 October 1970, Principle 1 of which states:

"The territory of a State shall not be the subject of acquisition by another State resulting from the threat or use of force. No territorial acquisition resulting from the threat or use of force shall be recognised as legal."

Note 14. See Crawford $(2012: 271)$ and Shaw $(2014: 426)$.

Note $15 . \quad$ UNCLOS $1982, \quad$ p. $7, \quad$ available at https://un.org/depts/los/convention_agreements/texts/unclos/unclos_e.pdf

Note 16. Delimitation of the Maritime Boundary in the Gulf of Maine Area (Canada v United States), Judgment, (1984) ICJ Reports, p. 246. 
Note 17. (1974) ICJ Reports, p. 3.

Note 18. (1974) ICJ Reports, p. 175.

Note 19. Award of 17 December 1999, RIAA Vol. XXII, p. 335 at 361, para. 101.

Note 20. In the Matter of The Chagos Marine Protected Area Arbitration, available at https://www.pcacase.com/pcados/MU-UK\%2020150318\%20Award.pdf

Note 21. Supra, note 13.

Note 22. See Judge Shigeru Oda's Dissenting Opinion in Continental Shelf (Tunisia/Libya Arab Jamahiriya) (1982) ICJ Reports 173 - 177.

Note 23. See United Nations, Division for Ocean Affairs and Law of the Sea, Declarations and Statements, at http://www.un.org/Depts/Los/convention_agreements/convention_declarations.htm

Note 24. See Allison and Blackwill (2013, p. xxvii).

Note 25. The Treaty of Mutual Cooperation and Security between Japan and the United States of America 1951 available at https://mofa.go.jp/region/n_american/us/q\&a/ref/1/html

Note 26. See Allison and Blackwill (2013 : 27-8); contrast Sen (1999 : 231).

Note 27. See Blackwill and Harris (2016: 113).

Note 28. Supra, note 5.

Note 29. See Rachman (2016: 49) (emphasis added).

Note 30. See Eritrea $v$ Yemen (Note 19 above), Chagos Maritime Protected Area (Mauritius $v$ United Kingdom) (Note 20 above) and the Philippines - China arbitration (Note 7 above).

\section{Copyrights}

Copyright for this article is retained by the author(s), with first publication rights granted to the journal.

This is an open-access article distributed under the terms and conditions of the Creative Commons Attribution license (http://creativecommons.org/licenses/by/4.0/). 